By these arrangements effective instruction in the museum is provided for 900 to Iooo children per week.

This work was undertaken in response to the appeal of the Education Committee, and in one sense at least it may be regarded as war emergency work. Its real value and usefulness have already been appreciated by the education authorities and by the teachers. But if the museum should be closed down, how can the work go on? What is to be done with the children? They have already been deprived of their schools by the military authorities. It is very desirable that they should not now be denied the valuable alternative instruction provided for them. The same problem will probably arise in many of the provincial towns in the country where similar work is being done.

The Manchester Museum.

W. M. Tattersall.

\section{A Relation between Atomic Weights and Radio-active Gonstants.}

THE interesting relation given by Mr. F. Gilbert Darruthers in NATURE of January 20 , p. $56_{5}$, holds, for

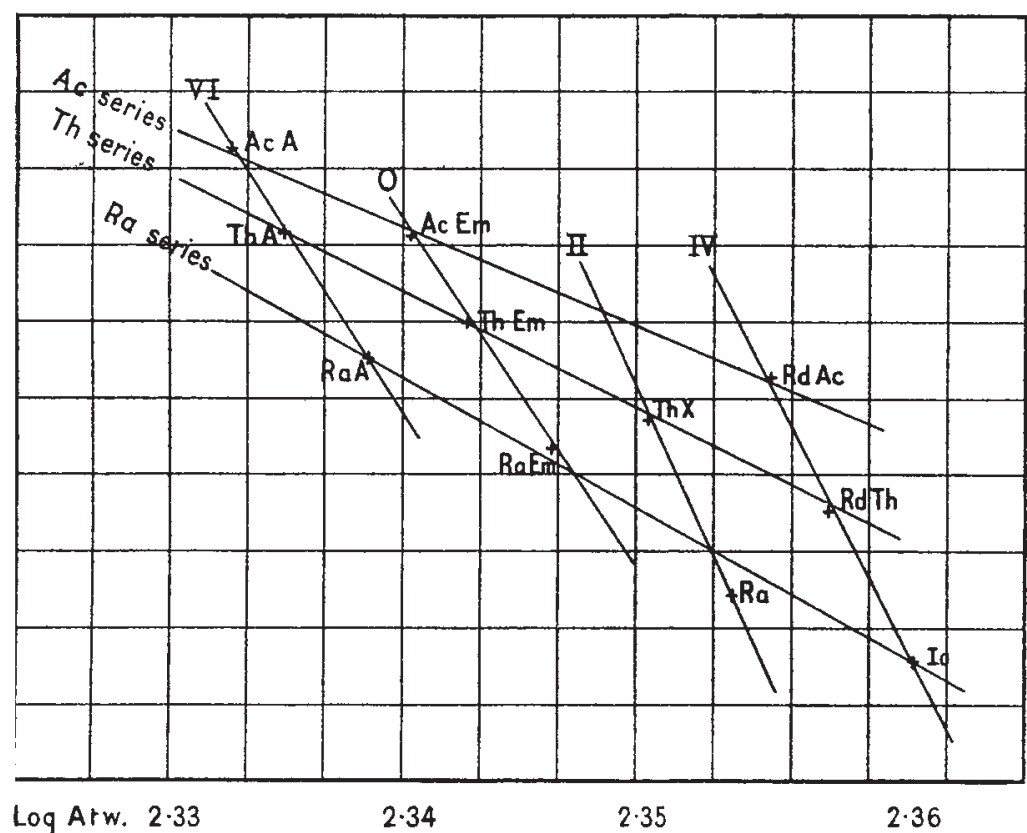

corresponding isotopes, nearly exactly, if, as suggestod by Fajans, the atomic weight of actinium should be 227 instead of 226 . From IV. to VI.B the only exception is AcX (and perhaps Ra). But the lines are not parallel, and not equally spaced.

Gorsel, Holland, January 25.

A. VAN DEN BROEk.

\section{Asteroids Feeding upon Living Sea-Anemones.}

As bearing upon the observations recorded by $\mathrm{Mr}$. H. N. Milligan in Nature of February 3, I should like to say that two of ten specimens of Eupargurus prideauxii, which have been kept in the aquarium of this institution since last autumn, died on January 23. The molluscan shell occupied by one of these specimens was that of Trochus magus, that occupied by the other was of Scaphander lignarius. Both shells were, as usual, enveloped by a specimen of the No. 2416 , VoL. 96] Range 0.8

anemone Adamsia palliata. When I first noticed the dead hermit-crabs both lay on the gravel at the bottom of the tank with their ventral surfaces uppermost, in both cases the abdomen was partially withdrawn from the molluscan shell. Both had been grown specimens of the asteroid Porania pulvillus, and the other by one rather larger specimen.

As I have for some time been interested in the feeding habits of Porania and Solaster, I wished to see what would happen and did not disturb the specimens until the following morning. I then found that no appreciable impression had been made by the starfishes upon the soft abdomens of the hermit-crabs; the enveloping anemone had discharged a considerable number of acontia, with which the actinal surfaces of the starfishes, and probably their partially everted stomachs, had been in contact.

My observations of the feeding habits of Porania have extended over two years, and I have invariably found it an exceedingly slow feeder. As shown by Gemmill (Proc. Zool. Soc., March, 1915, p. 13), this species is capable of subsisting for long periods upon microscopic food particles swept into the digestive tract by ciliary currents. My own observations tend to confirm those of Gemmill; and in view of such a capacity it appears to me to be remarkable that a voluntary attack should have been made upon so large a morsel as the abdomen of a Eupagurus, especially when protected, as is commonly assumed, by an actinian. The anemones did not show any outward sign of injury beyond partial relaxation of their hold upon the molluscan shells. H. C. Chadwick.

The Biological Station, Port Erin.

\section{Colourless Crystals of Hæmoglobin.}

Crystals of hæmatoidin in old blood extravasations in tissues are not-or at any rate have not been in the cases I have examined-soluble in chloroform or other solvents of bilirubin either with or without acidification. The colour dissolves out readily enough, but a transparent shape remains in the form of the original crystal. I have assumed that this remnant is a proteid basis similar to those which are well known in the crystals of urinary deposits and in calculi, and it is possible that Prof. Fraser Harris's curious experiences with hæmoglobin crystals are explicable along these lines. It is at least likely that hæmoglobin crystals prepared in the ordinary way contain also some serum proteid.

I7 Loom Lane, Radlett, February 4.

\section{Tubular Rock Structures.}

THE council of the Geophysics Society desires to obtain records of mineral growths taking the form of hollow cylinders-those not due to organisms, and 